\title{
EVALUASI PASCA HUNI ASPEK FUNGSIONAL PUSKESMAS PAL III KOTA PONTIANAK
}

\author{
Laili Rizki Amalia', Muhammad Nurhamsyah ${ }^{2}$, Lestari $^{3}$ \\ ${ }^{1}$ Mahasiswa, Program Studi Arsitektur, Fakultas Teknik, Universitas Tanjungpura. \\ amalialaililirizki@gmail.com \\ ${ }^{2}$ Program Studi Arsitektur, Fakultas Teknik, Universitas Tanjungpura \\ ${ }^{3}$ Program Studi Arsitektur, Fakultas Teknik, Universitas Tanjungpura
}

Naskah diajukan pada: 21 Desember 2020

Naskah revisi akhir diterima pada: 23 Desember 2020

\begin{abstract}
Abstrak
Pusat kesehatan masyarakat atau yang lebih dikenal sebagai Puskesmas adalah fasilitas kesehatan umum yang tersebar di Indonesia. Puskesmas Pal III merupakan salah satu pusat kesehatan masyarakat di Kota Pontianak yang telah didirikan dan beroperasi sejak tahun 1993. Peninjauan kembali terhadap bangunan Puskesmas Pal III diperlukan untuk penyesuaian kondisi bangunan saat ini dengan kebutuhan dan kenyamanan pengguna serta standar yang berlaku. Kegiatan peninjauan kembali bangunan yang telah dihuni ini merupakan evaluasi pasca huni (EPH). Penelitian ini menggunakan metode pendekatan campuran (kualitatif dan kuantitatif) yang membandingkan hasil kuesioner terhadap responden pasca huni bangunan yaitu petugas dan pengunjung dengan teori dan standar yang berlaku mengenai Puskesmas atau fasilitas kesehatan secara umum. Dalam prosesnya, analisis data dengan metode ini dihubungkan oleh tiga variabel aspek fungsional yaitu zonasi dan tata letak, sirkulasi, dan dimensi. Hasil penelitian menunjukkan bahwa ruang yang ada pada Puskesmas Pal III telah digunakan sesuai dengan fungsinya, hubungan ruang dirasa cukup nyaman serta telah memenuhi standar dan berkelompok berdasarkan fungsi pelayanan, serta sirkulasi pada bangunan Puskesmas yang cukup mudah dijangkau. Selain itu, dari beberapa sampel ruang yang diteliti, ukuran ruang sudah cukup luas bagi pengguna meskipun terdapat area yang tidak sesuai dengan standar yaitu area parkir motor pengunjung yang melebihi kapasitas tersedia.
\end{abstract}

Kata-kata Kunci: evaluasi pasca huni, puskesmas

\begin{abstract}
Community health center also known as Puskesmas are public healthcare facilities located across Indonesia. Puskesmas Pal III is a community health center in Pontianak which has been established and operating since 1993. A reevaluation is required to adjust current building condition to users needs, standards, and regulations. The re-evaluation is also known as post occupancy evaluation (POE). This study uses mixed methods (qualitative and quantitative) which compare the questionnaire results from building users as respondents to theories and standards regarding Community Health Center or health facilities in general. In the process, the data analysis using this method is connected by three functional aspect variables namely zoning and layout, circulation, and dimensions. The result of the study shows that the spaces in Puskesmas Pal III have been operating properly according to its function, the relationship between spaces is considered quite comfortable and have met the minimum standard also grouped based on the same function, and the circulation in the building is also considered comfortable. Moreover, from samples that have been studied, the space layout is considered quite spacious although there is an inadequate space which is over capacity in motorcycle parking areas for visitors.
\end{abstract}

Keywords: post occupancy evaluation, community health center

\section{Pendahuluan}

Fasilitas kesehatan adalah istilah umum yang merujuk kepada sarana atau prasarana atau perlengkapan yang diwujudkan dalam bentuk pelayanan yang diselenggarakan oleh pemerintah 
daerah, atau swasta bagi masyarakat dengan tujuan untuk menjaga atau meningkatkan kesehatan melalui tindakan preventif, kuratif, maupun rehabilitatif. Salah satu fasilitas kesehatan yang paling sering dijumpai di Indonesia adalah Puskesmas.

Berdasarkan Peraturan Menteri Kesehatan Republik Indonesia Nomor 75 Tahun 2014 tentang Pusat Kesehatan Masyarakat, Puskesmas atau pusat kesehatan masyarakat adalah unit pelaksana teknis dinas kabupaten/kota yang bertanggung jawab menyelenggarakan pembangunan kesehatan di suatu wilayah kerja. Jenis pelayanan kesehatan yang tersedia disesuaikan dengan kemampuan Puskesmas, namun terdapat upaya kesehatan wajib yang harus ditambah dengan upaya kesehatan pengembangan yang disesuaikan dengan permasalahan yang ada.

Bidang fisik merupakan suatu hal yang sangat penting bagi suatu bangunan. Bidang fisik antara lain mencakup bangunan, performansi ruang, tata lansekap, dan infrastruktur pendukung. Pada dasarnya fisik puskesmas juga berhubungan langsung dengan kualitas layanan medis. Bangunan yang berfungsi dengan baik akan memberikan tingkat kenyamanan yang tinggi dalam pemanfaatannya, sehingga memberikan sumbangan pada proses penyembuhan pasien dan produktivitas pelaku. Bangunan dengan fungsi dan kondisi yang baik juga akan memberikan jaminan bagi terlaksananya prosedur pelayanan medis yang diberikan.

Perencanaan pengembangan dalam rangka peningkatan fungsi dan pelayanan puskesmas selalu berdasarkan keadaan pada saat ini untuk mencapai kondisi yang lebih baik di masa yang akan datang. Untuk mengetahui keadaan pasti pada saat ini dari prasarana dan sarana fisik maka perlu dilakukan evaluasi pasca huni (EPH) yang merupakan kegiatan berupa peninjauan kembali terhadap bangunanbangunan atau lingkungan binaan yang telah dihuni. Evaluasi pasca huni akan mengkaji atau menilai kondisi fisik dan tingkat keberhasilan bangunan Puskesmas Pal III dalam memberikan pelayanan pada pemakai.

\section{Kajian Pustaka}

Evaluasi pasca huni menurut Suryadhi (2005) adalah kegiatan yang dilakukan untuk menilai tingkat kesesuaian antara bangunan dan lingkungan binaan dengan nilai-nilai dan kebutuhan penghuni bangunan. Evaluasi pasca huni juga dilakukan untuk memberikan masukan dalam merancang bangunan yang mempunyai fungsi yang sama. Evaluasi pasca huni bermanfaat untuk acuan jangka pendek, jangka menengah dan jangka panjang serta memberikan dukungan untuk meningkatkan kepuasan penghuni atas bangunan dan lingkungan binaan yang dihuni.

Menurut Sudibyo (1989), evaluasi pasca huni terbagi atas tiga aspek penting yakni fungsional, teknis, dan perilaku. Evaluator dapat melakukan evaluasi terhadap satu atau lebih aspek yang ada sesuai dengan kebutuhannya. Dalam pelaksanaan kegiatan evaluasi pasca huni terdapat empat tahap yang harus dilakukan yaitu perencanaan, pelaksanaan, analisis data, dan penerapan hasil.

Menurut Hatmoko (2010), kebanyakan fasilitas kesehatan sekarang berada dalam tahap penghunian dan pemanfaatan, oleh karena itu evaluasi terhadap fasilitas yang ada sangat diperlukan. Bagi fasilitas kesehatan, evaluasi pasca huni perlu dikaitkan dengan beberapa kategori yaitu pekerja, pengguna, dan setting. Lingkup yang yang harus diperhatikan pada kategori tersebut antara lain adalah standar fasilitas kesehatan dan standar arsitektur untuk fasilitas kesehatan.

\section{Metode}

Pada penelitian ini menggunakan pendekatan rasionalistik dengan metode campuran (kuantitatif dan kualitatif). Metode ini dipilih untuk memperoleh data yang lebih komprehensif, valid, dan objektif. Penelitian dilakukan dalam beberapa tahap yaitu, mengidentifikasi permasalahan pada bangunan, mendokumentasikan dan mendeskripsikan kondisi faktual bangunan, melakukan evaluasi terhadap bangunan berdasarkan teori dan standar yang berlaku, menganalisa data dari hasil evaluasi, dan merumuskan hasil dari proses analisa. 
Evaluasi pasca huni yang dilakukan Puskesmas Pal III dilakukan terhadap aspek fungsional pada bangunan. Variabel penelitian dilihat dari tiga aspek fungsional yaitu, zonasi tata letak, sirkulasi, dan dimensi. Indikator yang digunakan dalam aspek zonasi tata letak adalah fungsi ruang, suasana ruang, dan hubungan ruang. Indikator yang digunakan dalam aspek sirkulasi adalah alur/akses, tipe sirkulasi, dan jenis sirkulasi. Indikator yang digunakan dalam aspek dimensi adalah ukuran ruang, dan furniture.

Pengumpulan data dilakukan melalui observasi langsung pada kondisi eksisting Puskesmas Pal III dan memberikan kuesioner kepada responden yaitu petugas dan pengunjung. Kuesioner yang digunakan tersusun atas pertanyaan yang berkaitan dengan variabel penelitian terhadap aspek fungsional. Data yang didapat dari hasil observasi dan hasil kuesioner kemudian menjadi acuan untuk dibandingkan dengan teori dan standar terkait fasilitas kesehatan. Hasil akhir berupa kesimpulan yang menyatakan bahwa apakah Puskesmas Pal III Kota Pontianak telah sesuai dengan standar yang ada atau tidak.

Objek penelitian adalah Puskesmas Pal III yang beralamat di Jalan Puskesmas Pal III, atau di Gg. Usman Gani Kelurahan Sungai Jawi, Kecamatan Pontianak Kota. Pencapaian menuju bangunan mudah diakses karena dapat dilalui kendaraan roda dua dan roda empat. Orientasi bangunan Puskesmas Pal III menghadap ke arah utara, tepatnya menghadap jalan Puskesmas Pal III. Bagian barat Puskesmas berbatasan dengan warung makan Ezar, sebelah timur berbatasan dengan Gg. Usman Gani serta bagian selatan Puskesmas berbatasan dengan toko pakaian wanita (Vania Collection). Puskesmas Pal III memiliki luas $2256 \mathrm{~m}^{2}$ dengan ukuran bangunan $324 \mathrm{~m}^{2}$. Puskesmas Pal III berdiri pada tahun 1993 dan merupakan Puskesmas non rawat inap. Pada awalnya Puskesmas Pal III merupakan Puskesmas Pembantu (Pustu) yang merupakan pindahan dari Pustu di Jalan Apel. Sejak dipindahkan, puskesmas tersebut berorientasi menghadap Gg. Usman Gani. Pada tahun 2011 Puskesmas mulai dibangun secara bertahap hingga mencapai kondisi saat ini.

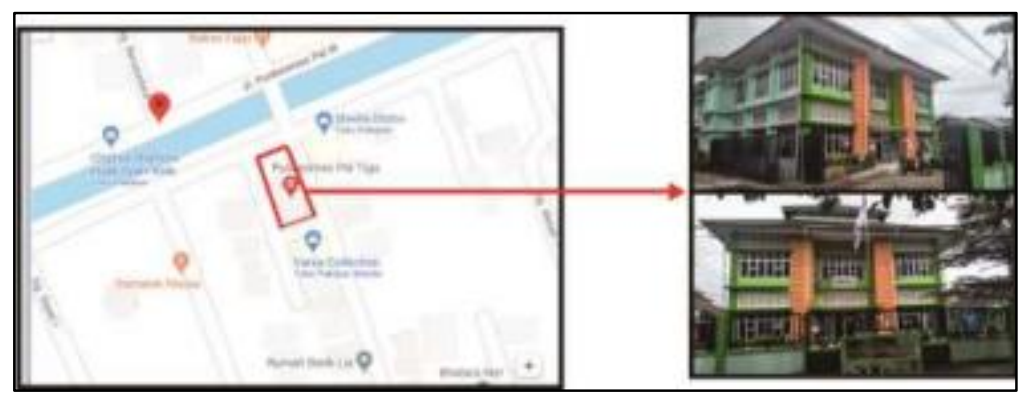

Gambar 1. Peta lokasi dan bangunan Puskesmas Pal III Sumber: Penulis, 2020

\section{Hasil dan Pembahasan}

Evaluasi zonasi tata letak pada aspek fungsional Puskesmas Pal III Kota Pontianak mencakup hubungan antar ruang dan sifat ruang. Untuk petugas, pertanyaan pada kuesioner difokuskan kepada ruang kerja masing-masing. Untuk pengunjung, pertanyaan pada kuesioner difokuskan kepada ruang yang paling sering digunakan yaitu ruang pendaftaran, ruang tunggu, dan ruang periksa. Pembahasan zonasi tata letak dikelompokkan ke dalam beberapa bagian yaitu kesesuaian fungsi ruang, suasana ruang, hubungan ruang kerja.

\section{Fungsi Ruang}

Ruang pendaftaran terletak dekat dengan pintu utama masuk Puskesmas Pal III. Pada ruang pendaftaran pasien terlebih dahulu mengambil nomor antrian yang terletak dekat dengan pintu masuk utama Puskesmas dan pintu masuk ruang tindakan. Setelah itu pasien menunggu untuk dapat dilayani oleh petugas yang ada di ruang pendaftaran. Setelah pasien mendapatkan pelayanan dari petugas pendaftaran, selanjutnya pasien menunggu diruang tunggu mengantri masuk ke ruang periksa. 
Ruangan pendaftaran berfungsi sesuai dengan fungsinya. Pada ruang tunggu pasien yang mengantri dibagi menjadi dua, ada yang mengantri untuk dipanggil oleh petugas pendaftaran dan menunggu antrian untuk mendapat layanan dari ruang periksa. Fungsi pada ruang tunggu berfungsi sebagaimana fungsinya, namun pada ruang tunggu tersebut tak banyak pula pasien atau keluarga pasien yang berdiri saat menunggu antrian.

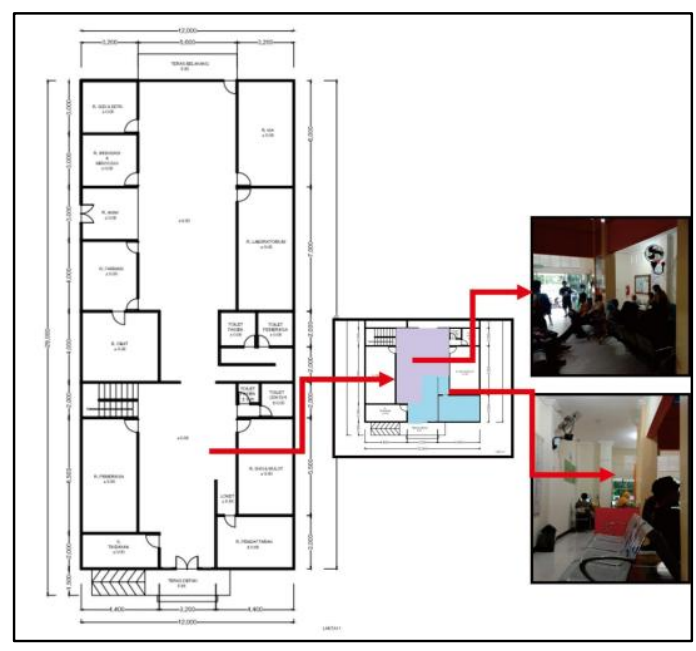

Gambar 2. Denah ruang pendaftaran dan ruang tunggu Puskesmas Pal III Sumber: Penulis, 2020

Laboratorium berada tepat di sebelah ruang KIA dan toilet petugas puskesmas. Pada laboratorium terdapat dua ruang yang dipisah dengan menggunakan dinding kaca yang memiliki fungsi yang berbeda. Ruang pertama merupakan ruang untuk mengambil sampel pada pasien serta pendataan sedangkan ruang yang kedua berfungsi untuk mengukur hasil sampel yang sudah diambil dari pasien. Setelah itu hasil yang didapatkan akan diserahkan kepada dokter atau bidan untuk menjelaskan hasil pemeriksaan laboratorium kepada pasien. Laboratorium tersebut digunakan sesuai dengan fungsinya.

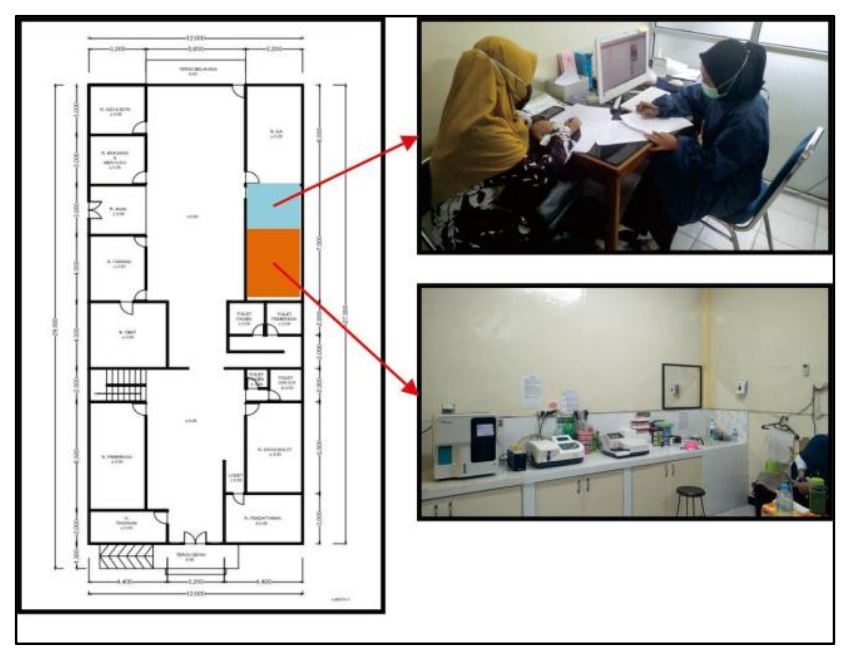

Gambar 3. Denah laboratorium Puskesmas Pal III Sumber: Penulis, 2020

Ruang tata usaha yang terletak pada lantai dua bangunan puskesmas merupakan ruang yang sering dikunjungi oleh pasien yang meminta surat keterangan dokter. Ruangan tersebut juga sebagai 
tempat untuk urusan surat menyurat ataupun tempat penyimpanan data-data yang berkaitan dengan Puskesmas Pal III. Ruang tata usaha tersebut digunakan sesuai dengan fungsinya.

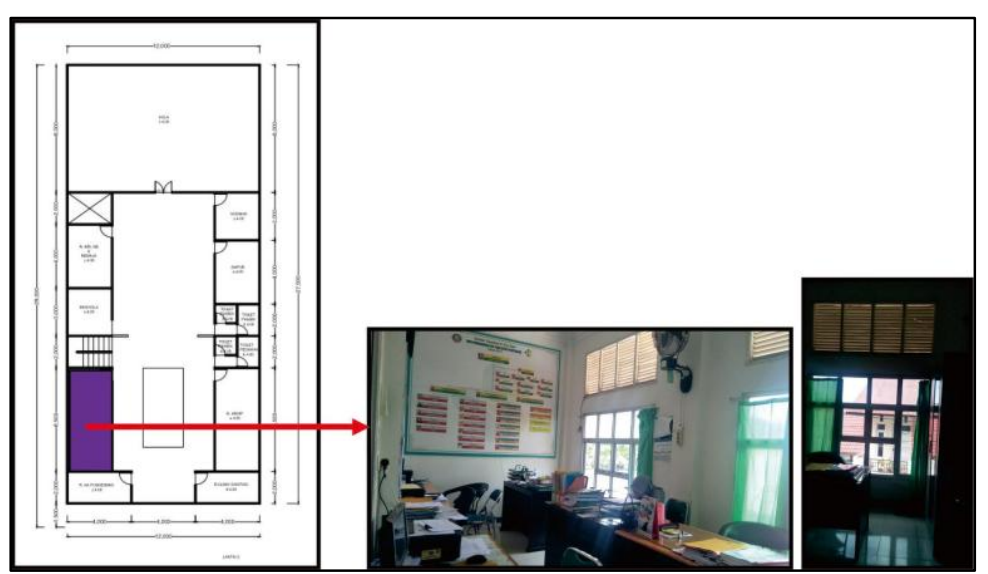

Gambar 4. Denah ruang tata usaha Puskesmas Pal III Sumber: Penulis, 2020

Pada Puskesmas Pal III terdapat dua ruang toilet karyawan dan dua ruang toilet untuk pasien yang terletak pada masing-masing lantai puskesmas tersebut. Toilet pasien pada lantai satu terdapat dua ruang. Namun salah satu toilet tersebut tidak digunakan dan difungsikan sebagai gudang. Toilet pasien pada lantai dua kurang difungsikan karena jarang digunakan oleh pasien sehingga sering ditutup. Toilet karyawan puskesmas yang terletak di lantai satu posisinya sedikit tersembunyi dan memiliki sebuah lorong kecil saat memasukinya. Sedangkan toilet karyawan pada lantai dua terlihat jelas bersebelahan dengan toilet pasien.

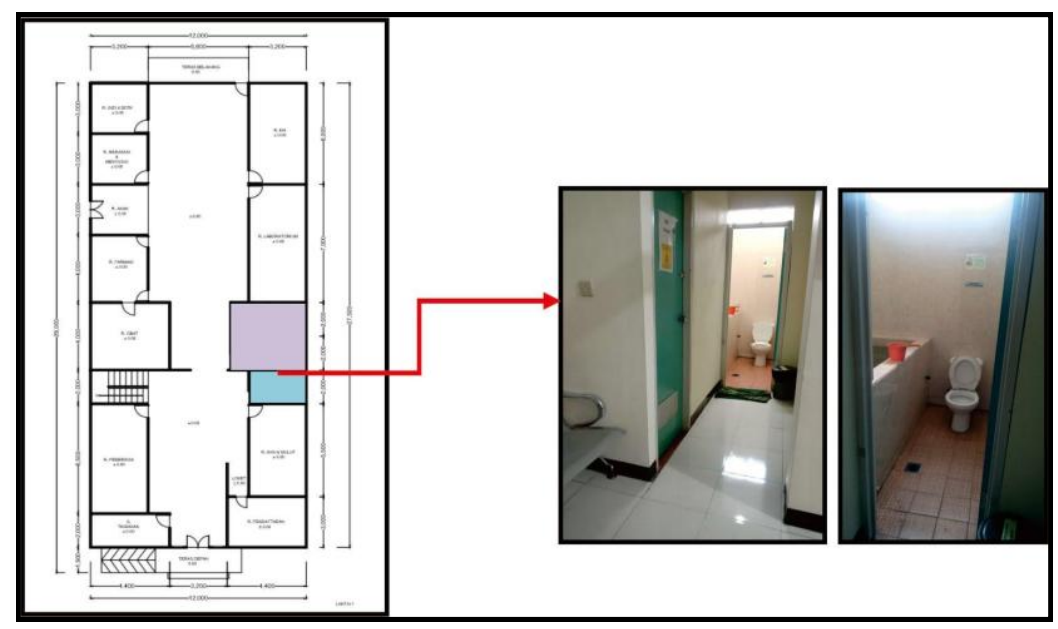

Gambar 5. Denah toilet Puskesmas Pal III Sumber: Penulis, 2020

Pada Puskesmas Pal III hanya tersedia lahan parkir untuk kendaraan roda dua. Karena lahan parkir yang disediakan tidak terlalu luas, parkir kendaraan pasien/pengunjung dan parkir kendaraan petugas terpisah. Untuk parkir kendaraan pengunjung terletak pada entrance bangunan sedangkan parkir untuk petugas terletak pada bagian belakang bangunan. Karena kurangnya lahan untuk parkir kendaraan untuk pasien/pengunjung, tidak jarang kendaraan tersebut diparkir hingga ke badan jalan Gg. H.Usman Gani. Sedangkan untuk kendaraan roda empat diparkir di sekitar tepi jalan puskesmas Pal III yang dapat mengganggu pengendara yang lewat jalan tersebut. 


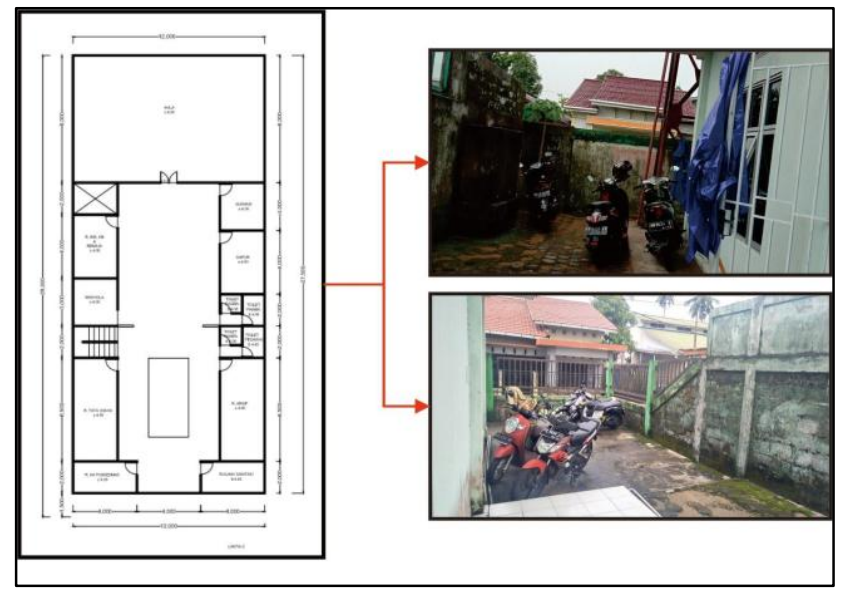

Gambar 6. Denah area parkir Pal III

Sumber: Penulis, 2020

Hasil responden terkait dengan kesesuaian fungsi ruang pada Puskesmas Pal III Kota Pontianak dapat dilihat pada Gambar 7.

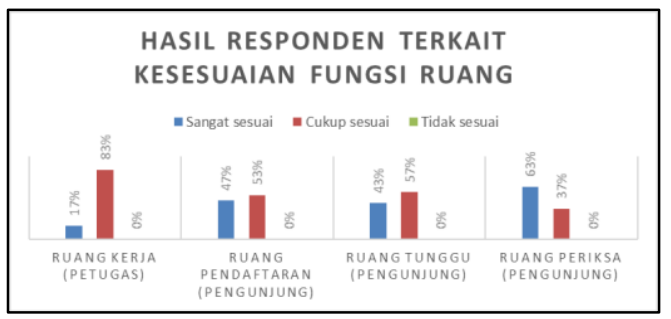

Gambar 7. Grafik hasil responden terkait kesesuaian fungsi ruang Sumber: Penulis, 2020

Kesimpulan menurut hasil pasca huni terkait kesesuaian fungsi banguan pada bangunan Puskesmas Pal III para responden yaitu petugas dan pengunjung menyatakan bahwa ruang pada bangunan Puskesmas Pal III sudah sesuai dengan fungsinya serta kondisi dilapangan yang menunjukkan ruang-ruang yang ada sudah sesuai dengan fungsinya.

\section{Suasana Ruang}

Ruang pendaftaran terletak dekat dengan pintu utama masuk Puskesmas Pal III. Suasana pada ruang pendaftaran terlihat petugas yang dikelilingi oleh berbagai berkas pasien. Pada ruang tersebut juga memiliki bukaan berupa jendela dari dua sisi bangunan yang membuat suasana ruang tersebut mendapatkan udara segar masuk kedalam ruangan. Selain itu, pada ruangan tersebut juga dilengkapi dengan pendingin ruang tambahan untuk menambah kenyamanan pengguna saat berada didalam ruangan tersebut. Pada ruang pendaftaran juga dilengkapi dengan penerangan buatan yang digunakan saat cuaca diluar mulai gelap atau mendung. Ruang tunggu yang berhubungan langsung dengan loket pendaftaran tersebut dilengkapi dengan pencahayaan dan penghawaan buatan. Karena pada ruang tunggu tersebut tidak cukup banyak memiliki bukaan yang membuat udara dan cahaya masuk ke dalam ruangan, maka pada ruang tunggu penghawaan buatan berupa kipas angin dan lampu tersebut digunakan setiap saat. Selain itu, pada ruang tunggu juga memiliki tingkat kebisingan yang cukup tinggi. Karena ramainya pengunjung yang menunggu antrian untuk masuk ke ruang periksa atau pun juga menunggu antrian pada loket pendaftaran sering berbincang serta terdengar juga suara monitor pemanggil nomor antrian yang terkadang tidak terdengar oleh pasien yang menunggu membuat petugas memanggil kembali. 


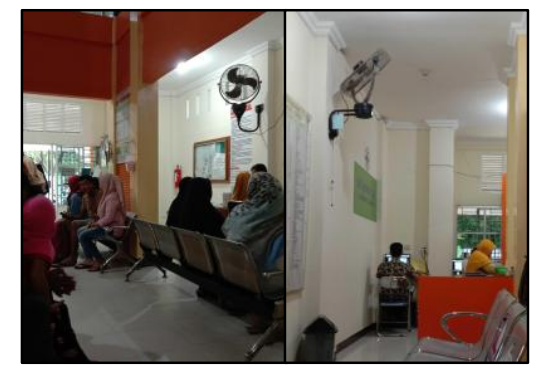

Gambar 8. Ruang pendaftaran dan ruang tunggu Sumber: Penulis, 2020

Laboratorium yang terletak pada lantai satu bangunan puskesmas yang bersebelahan dengan ruang KIA dan toilet pegawai tersebut dilengkapi dengan bukaan berupa ventilasi dan jendela pada ruangan sebagai sirkulasi udara dan cahaya masuk ke dalam ruangan. Selain itu, laboratorium juga menggunakan penghawaan dan penerangan buatan berupa kipas angin dan lampu. Laboratorium dipisahkan oleh dinding partisi perupa dinding yang terbuat dari kaca. Pemisah tersebut digunakan untuk memisahkan antara ruang periksa atau ruang pengambilan sampel dan ruang pengujian hasil.

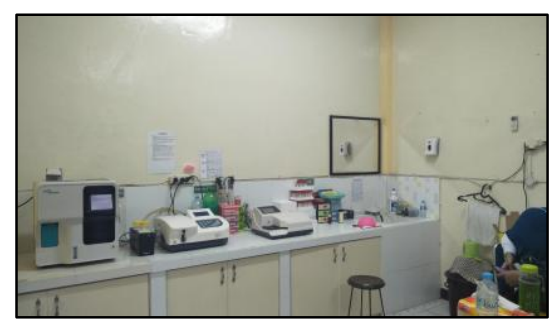

Gambar 9. Laboratorium

Sumber: Penulis, 2020

Suasana ruang pada ruang tata usaha, ruangan tersebut dilengkapi dengan berbagai macam furniture yang membuat ruang tersebut terlihat sempit. Selain itu, ruangan tersebut dilengkapi juga dengan pencahayaan alami dan buatan. Pencahayaan alami diperoleh dari bukaan jendela dan ventilasi sedangkan pencahayaan buatan diperoleh dari lampu. Begitu juga dengan penghawaan pada ruang tata usaha dilengkapi dengan penghawaan buatan berupa kipas angin.

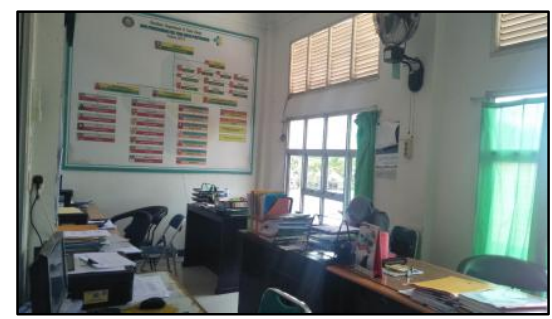

Gambar 10. Ruang tata usaha

Sumber: Penulis, 2020

Pada Puskesmas Pal III terdapat dua ruang toilet karyawan dan dua ruang toilet untuk pasien yang terletak pada masing-masing lantai pada puskesmas tersebut. Toilet pasien pada lantai satu terdapat dua ruang, namun salah satu toilet tersebut tidak difungsikan sebagai toilet atau rusak, saat ini difungsikan sebagai gudang. Toilet pasien pada lantai dua kurang difungsikan karena jarang dipakai oleh pasien. Toilet karyawan puskesmas yang terletak di lantai satu posisinya sedikit tersembunyi dan memiliki sebuah lorong kecil saat memasukinya serta dilengkapi dengan ventilasi kecil sebagai tempat 
pertukaran udara. Sedangkan toilet karyawan pada lantai dua terlihat jelas bersebelahan dengan toilet pasien.

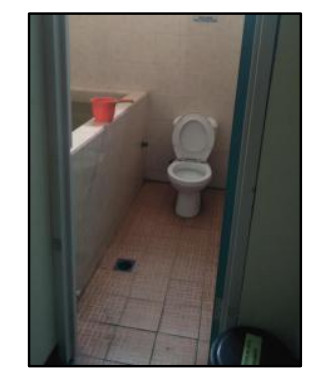

Gambar 11. Toilet

Sumber: Penulis, 2020

Area parkir pada Puskesmas Pal III hanya tersedia lahan parkir untuk kendaraan roda dua. Karena lahan parkir yang disediakan tidak terlalu luas, parkir kendaraan pasien/pengunjung dan parkir kendaraan petugas terpisah. Untuk parkir kendaraan pengunjung terletak pada entrance bangunan sedangkan parkir untuk petugas terletak pada bagian belakang bangunan. Karena kurangnya luas lahan untuk parkir kendaraan untuk pasien/pengunjung, tidak jarang kendaraan tersebut diparkir hingga ke badan jalan gg. H.Usman gani. Sedangkan untuk kendaraan roda empat diparkir di sekitar tepi jalan puskesmas pal III yang dapat mengganggu pengendara yang lewat jalan tersebut.

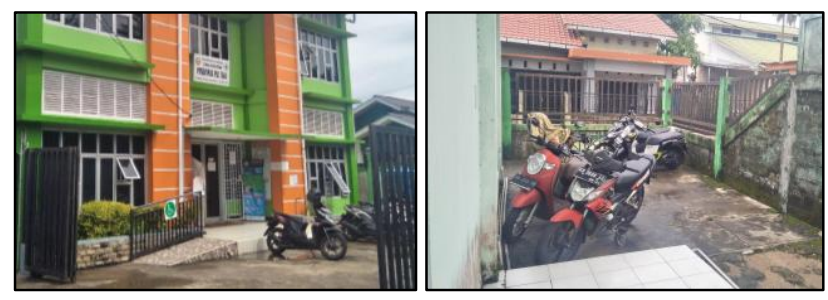

Gambar 12. Area parkir petugas dan pengunjung Sumber: Penulis, 2020

Hasil responden terkait dengan suasana ruang dan kualitas ruang (pencahayaan, penghawaan, akustik) pada Puskesmas Pal III Kota Pontianak dapat dilihat pada Gambar 13.
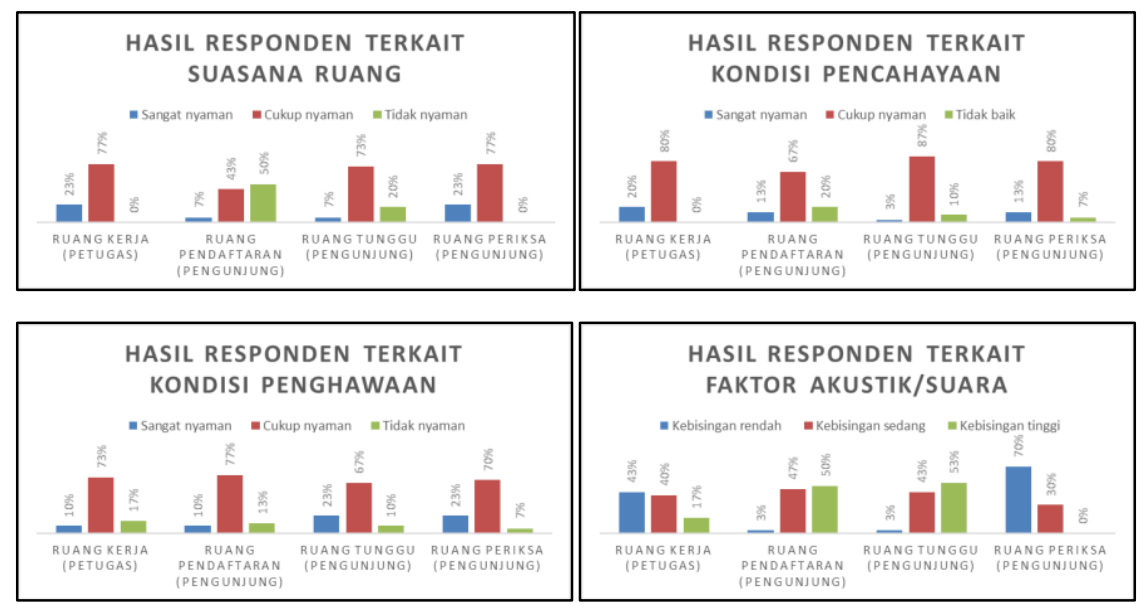

Gambar 13. Grafik hasil responden terkait suasana ruang dan kualitas ruang Sumber: Penulis, 2020 
Dari hasil amatan serta kuesioner pengguna Puskesmas menunjukan bahwa suasana pada ruangruang kerja pengguna cukup nyaman, maka dapat disimpulkan bahwa suasana ruang pada Puskesmas Pal III cukup nyaman dilihat dari kuesioner terkait dengan kualitas ruangan yang menunjukkan bahwa kondisi tersebut sudah cukup bagi pengguna

\section{Hubungan Ruang}

Ruang pendaftaran yang terletak dekat dengan pintu masuk utama puskesmas Pal III yang berhubungan langsung dengan ruang tunggu serta hubungan tak langsung dengan ruang periksa gigi dan ruang-ruang yang lain. Petugas yang bertugas mengantar kartu periksa pasien ke setiap ruang periksa harus berjalan lebih jauh.

Ruang tunggu yang letaknya berhubungan tidak langsung dengan ruang periksa pasien serta berhubungan langsung dengan ruang pendaftaran. Ruangan tersebut tertak di area yang bisa dikatakan seperti lorong yang berada di tengah-tengah antara ruang-ruang periksa.

Letak laboratorium bersebelahan dengan ruang KIA dan toilet pegawai serta berhubungan tidak langsung dengan ruang-ruang yang berada pada lantai satu dan tidak berhubungan dengan ruang-ruang yang berada pada lantai dua bangunan puskesmas pal III.

Ruang tata usaha yang terletak pada lantai dua bangunan puskesmas tepatnya sebelah kanan tangga bangunan serta berhubungan tidak langsung dengan ruang kepala UPK puskesmas. Ruang tata usaha juga tidak langsung dengan ruang-ruang yang ada pada lantai dua. Selain itu ruang tata usaha juga terletak dekat dengan void pada lantai dua, yang mana void tersebut berhubungan dengan ruang tunggu pada lantai satu. Ruang tata usaha tersebut juga tidak berhubungan dengan ruang-ruang yang ada pada lantai satu.

Toilet yang berada pada puskesmas pal III, terdapat empat ruang toilet yang berada pada lantai satu dan lantai dua bangunan. Toilet pada lantai satu, terdapat toilet pengunjung atau pasien yang bersebelahan dengan ruang periksa gigi dan mulut serta toilet karyawan. Selain itu, toilet pengunjung juga terletak dekat dengan ruang tunggu pasien. Sedangkan toilet pegawai puskesmas terletak dekat dengan ruang laboratorium yang terletak diantara ruang transisi bangunan. Untuk toilet pada lantai dua bangunan, terletak bersebelahan dengan ruang dapur untuk toilet pengunjung dan bersebelahan dengan ruang arsip untuk toilet pegawai puskesmas.

Lahan parkir pengunjung puskesmas berhubungan langsung dengan entrance bangunan puskesmas yang letaknya pada bagian depan bangunan sedangkan lahan parkir untuk pegawai puskesmas berhubungan langsung dengan pintu masuk bagian belakang puskesmas dan terletak pada bagian belakang bangunan puskesmas.

Hasil responden terkait dengan hubungan ruang pada Puskesmas Pal III Kota Pontianak dapat dilihat pada Gambar 14.

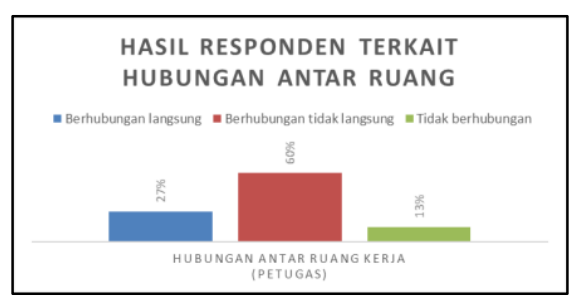

Gambar 14. Grafik hasil responden terkait hubungan antar ruang Sumber: Penulis, 2020

Kesimpulannya adalah kebanyakan ruang pada Puskesmas Pal III berhubungan tidak langsung satu sama lain. Sesuai dengan peraturan pemerintah dan kuesioner, maka hubungan ruang pada Puskesmas Pal III Kota Pontianak sudah memenuhi standar hubungan ruang karena zonasi tata letak hubungan ruangnya dikelompokan berdasarkan fungsi pelayanannya. 


\section{Sirkulasi}

Akses masuk pengunjung atau pasien menuju ruang pendaftaran dapat dicapai melalui pintu masuk utama bangunan puskesmas pal III. Sedangkan untuk pegawai puskesmas dapat dicapai melalui pintu utama ataupun pintu masuk belakang bangunan puskesmas. Untuk pegawai yang akan melaksanakan pekerjaannya dapat masuk ke dalam ruangannya dengan melewati ruang tunggu yang setiap harinya padat akan pasien. Akses masuk menuju ruang tunggu pasien dapat dicapai melalui pintu masuk utama serta pintu masuk belakang.

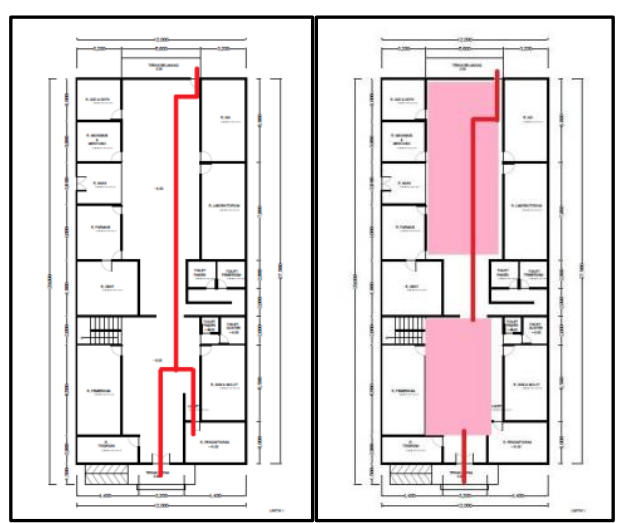

Gambar 15. Alur sirkulasi ruang pendaftaran dan ruang tunggu

Sumber: Penulis, 2020

Akses masuk menuju laboratorium dapat dicapai melalui pintu masuk utama dengan melewati ruang pendaftaran, ruang tunggu pasien. Selain itu juga dapat diakses melalui pintu masuk belakang bangunan dengan melewati ruang tunggu pasien yang berada di depan ruang KIA. Ruang tata usaha yang terletak pada lantai dua bangunan puskesmas pal III dapat diakses dengan melalui pintu masuk utama dan pintu masuk belakang dengan melewati ruang tunggu pasien kemudian menaiki tangga yang berada dekat dengan ruang periksa dokter umum lalu melewati ruang tunggu yang berada di depan ruang tata usaha tersebut.

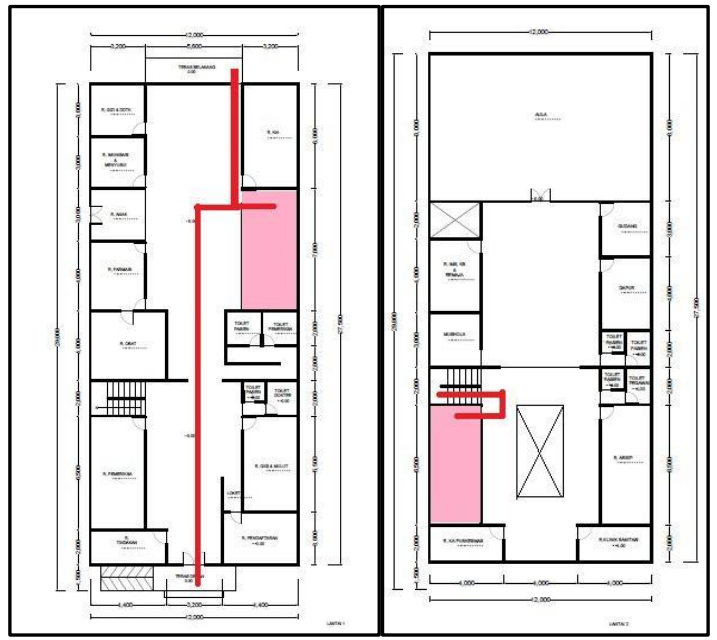

Gambar 16. Alur sirkulasi laboratorium dan ruang tata usaha Sumber: Penulis, 2020

Toilet pada lantai satu dapat diakses melalui pintu masuk utama dan pintu masuk belakang, kemudian melewati ruang tunggu yang berada di lobby bangunan dan toilet tersebut berada dekat dengan ruang periksa gigi dan mulut serta di ruang transisi bangunan pada lantai satu. Sedangkan untuk mengakses toilet yang berada dilantai dua dapat menaiki tangga dan menuju langsung ke arah toilet 
yang berada dekat dengan ruang arsip dan di depan mushola banguanan pusksesmas pal III. Selain itu toilet untuk pegawai dapat diakses dari ruangan kerja masing-masing pegawai.

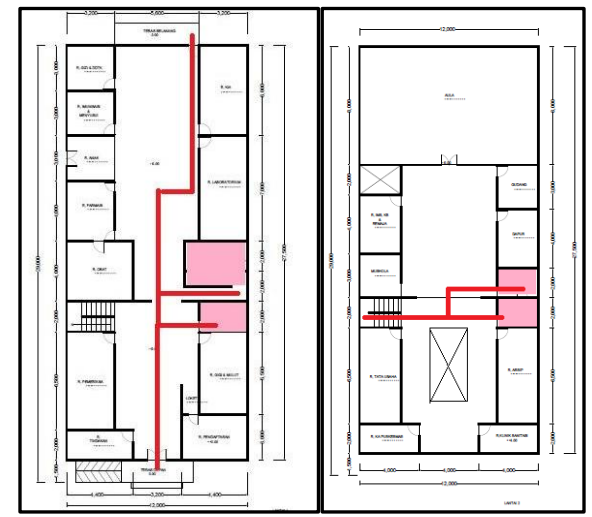

Gambar 17. Alur sirkulasi toilet

Sumber: Penulis, 2020

Area parkir pengunjung dapat diakses melalui entrance masuk area puskesmas yang berada di depan bangunan. Pengunjung dapat memarkirkan kendaraan roda pada area parkir yang sudah tersedia. Untuk area parkir pegawai puskesmas dapat diakses melalui pintu masuk samping gedung puskesmas yang memang difungsikan sebagai pintu masuk kendaraan pegawai menuju area parkir.

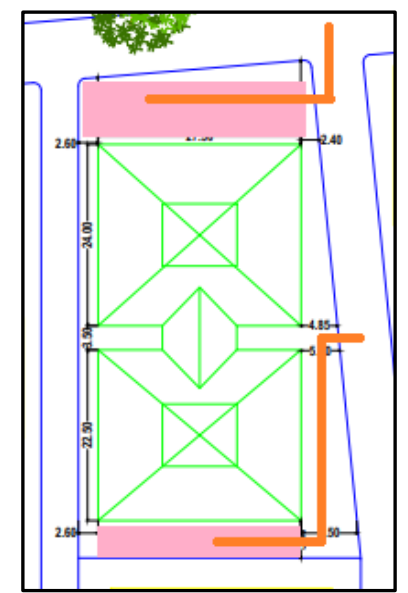

Gambar 18. Alur sirkulasi menuju area parkir

Sumber: Penulis, 2020

Hasil responden terkait dengan jalur sirkulasi dalam bangunan pada Puskesmas Pal III Kota Pontianak dapat dilihat pada Gambar 19.

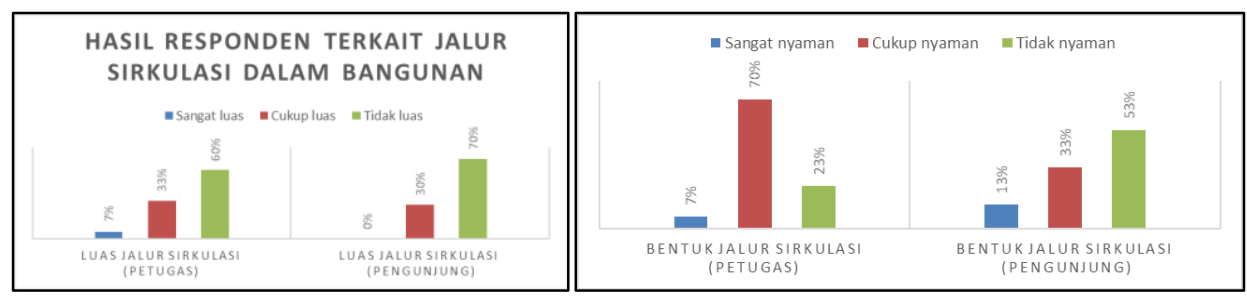

Gambar 19. Grafik hasil responden terkait jalur sirkulasi dalam bangunan Sumber: Penulis, 2020 
Hasil responden terkait dengan akses pencapaian antar ruang kerja pada Puskesmas Pal III Kota Pontianak dapat dilihat pada Gambar 20.

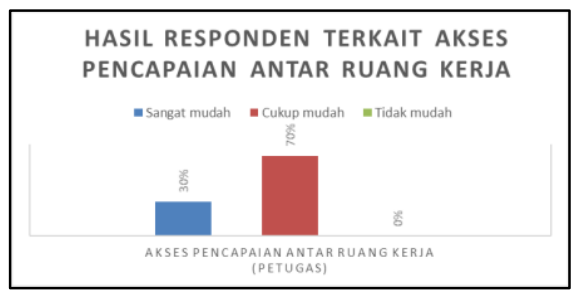

Gambar 20. Grafik hasil responden terkait pencapaian antar ruang kerja Sumber: Penulis, 2020

Hasil responden terkait dengan akses menuju bangunan Puskesmas Pal III Kota Pontianak dapat dilihat pada Gambar 21.

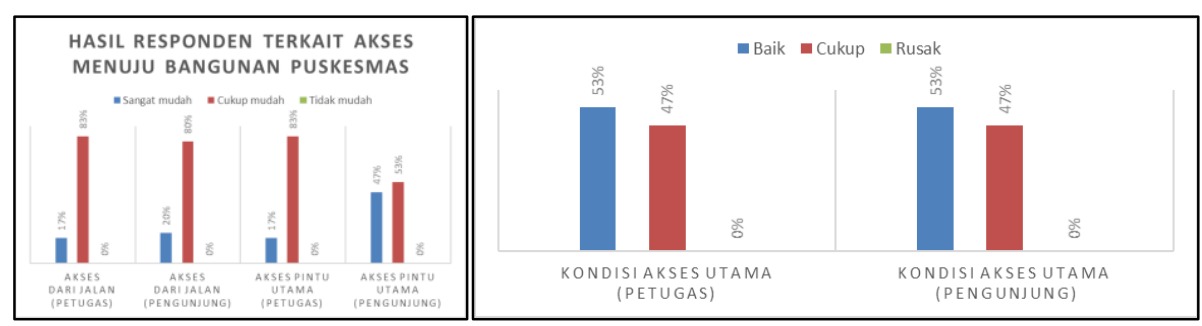

Gambar 21. Grafik hasil responden terkait pencapaian antar ruang kerja Sumber: Penulis, 2020

Hasil responden terkait dengan akses menuju area servis pada Puskesmas Pal III Kota Pontianak dapat dilihat pada Gambar 22.

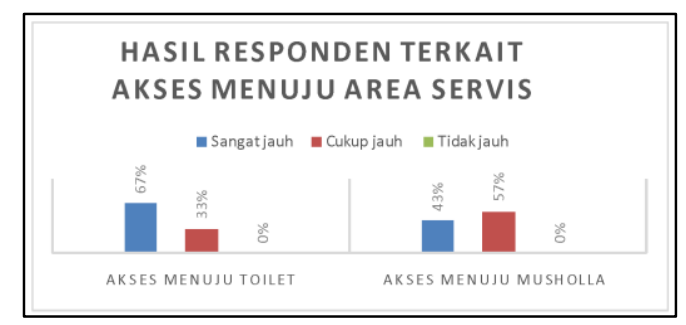

Gambar 22. Grafik hasil responden terkait akses menuju area servis Sumber: Penulis, 2020

Hasil responden terkait dengan kemudahan area parkir pada Puskesmas Pal III Kota Pontianak dapat dilihat pada Gambar 23.

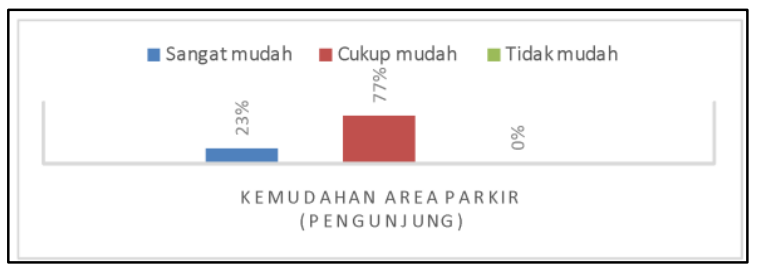

Gambar 23. Grafik hasil responden terkait kemudahan area parkir Sumber: Penulis, 2020 
Berdasarkan Peraturan Menteri Kesehatan RI Nomor 75 Tahun 2014, alur kegiatan puskesmas bagi pasien rawat jalan dapat menggambarkan hubungan ruang dalam puskesmas. Dari hasil kuesioner dan kondisi di lapangan terkait alur kegiatan bagi pengunjung dan petugas puskesmas cukup mudah dijangkau, namun responden juga menyatakan ada beberapa titik yang memang sirkulasi dalam bangunan yang tidak luas.

\section{Dimensi}

Ruang pendaftaran pada puskesmas pal III memiliki bentuk persegi panjang dengan ukuran 4.40 x $3.00 \mathrm{~m}^{2}$. Ukuran besaran ruang untuk ruang pendaftaran dan rekam medik pada Permenkes Nomor 75 tahun 2014 tentang pusat kesehatan masyarakat memiliki standar minimal $16 \mathrm{~m}^{2}$ dan hanya dibutuhkan satu unit. Jadi fakta di lapangan untuk besaran ruang pendaftaran dan rekam medik di Puskesmas Pal III tidak memenuhi standar besaran minimal, karena pada fakta di lapangan ukuran ruang pendaftaran berukuran kurang lebih $12 \mathrm{~m}^{2}$. Ruang tunggu yang memiliki bentuk memanjang yang terletak di tengah antar ruang periksa tersebut memiliki ukuran $10.50 \times 5.60 \mathrm{~m}^{2}$.

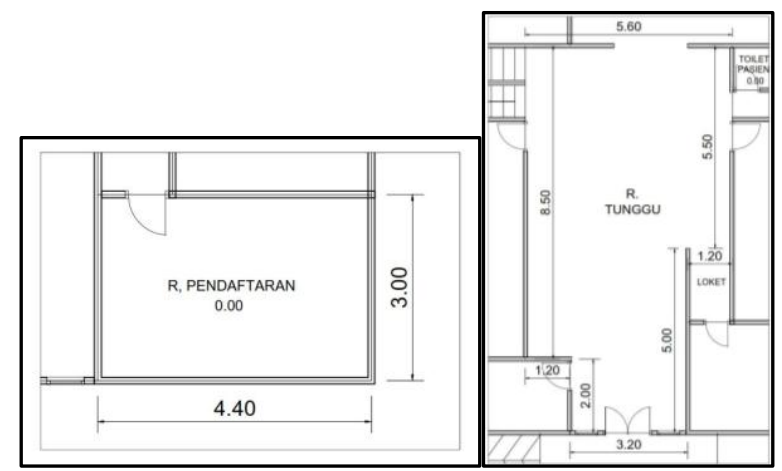

Gambar 24. Ukuran ruang pendaftaran dan ruang tunggu

Sumber: Penulis, 2020

Laboratorium memiliki bentuk persegi panjang dengan luas 7.00 x $3.20 \mathrm{~m}^{2}$. Dalam Peraturan Menteri Kesehatan RI Nomor 37 Tahun 2012 tentang Penyelenggaraan Laboratorium Pusat Kesehatan Masyarakat menjelaskan bahwa untuk ukuran laboratorium puskesmas minimal $3 \times 4 \mathrm{~m}^{2}$. Jadi untuk ukuran laboratorium puskesmas pal III sudah memenuhi standar minimum. Ruang tata usaha pada puskesmas memiliki ukuran $6.50 \times 2.80 \mathrm{~m}^{2}$. Besaran ruang tata usaha menurut Permenkes Nomor 75 tahun 2014 tentang pusat kesehatan masyarakat memiliki ukuran $20 \mathrm{~m}^{2}$ untuk satu unit. Sedangkan dalam fakta dilapangan hanya memiliki ukuran $18.2 \mathrm{~m}^{2}$, jadi ruangan tersebut tidak memenuhi standar ukuran minimal ukuran ruang.

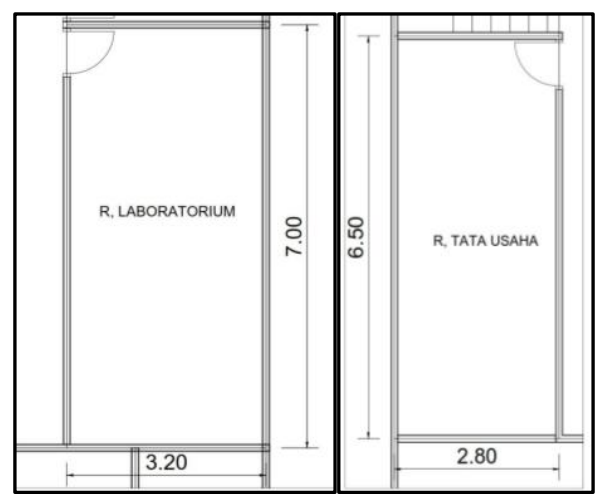

Gambar 25. Ukuran laboratorium dan ruang tata usaha Sumber: Penulis, 2020 
Toilet pada puskesmas pal III terdapat pada lantai satu dan lantai dua, toilet pada lantai dua memiliki ukuran yang sama yaitu $2.80 \times 2 \mathrm{~m}^{2}$. Sedangkan toilet pengunjung pada lantai satu memiliki ukuran $3.20 \times 2 \mathrm{~m}^{2}$ dan toilet petugas memiliki ukuran $3.80 \times 4 \mathrm{~m}^{2}$. Menurut Peraturan Menteri Kesehatan Nomor 75 Tahun 2014 tentang pusat kesehatan masyarakat, toilet petugas dan pengunjung puskesmas dipisah antara toilet wanita dan pria dan memiliki besaran ruang $4 \mathrm{~m}^{2}$ sebanyak dua unit. Sedangkan fakta di lapangan untuk toilet pengunjung hanya ada satu unit yang fungsi meskipun terdapat dua unit toilet yang tersedia dan ukuran besaran ruang satu unit toilet pengunjung pada lantai satu $3.80 \mathrm{~m}^{2}$ yang difungsikan serta di lantai dua memiliki ukuran besaran ruang $4 \mathrm{~m}^{2}$ dan berfungsi untuk kedua-duanya. Toilet petugas puskesmas pada lantai satu memiliki ukuran besaran ruang $4.2 \mathrm{~m}^{2}$ untuk masing-masing toilet sedangkan untuk toilet pegawai pada lantai dua memiliki ukuran besaran ruang $2.8 \mathrm{~m}^{2}$ untuk satu toilet dan terdapat ruang untuk wudhu yang berukuran $1.68 \mathrm{~m}^{2}$.

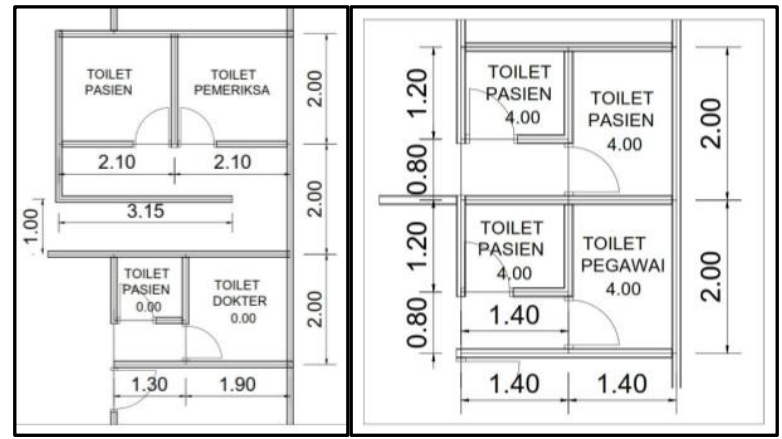

Gambar 26. Ukuran toilet

Sumber: Penulis, 2020

Fakta di lapangan ukuran parkir roda dua puskesmas pal III, untuk parkir kendaraan roda dua bagi pengunjung memiliki ukuran kurang lebih $121.50 \mathrm{~m}^{2}$ dan parkir kendaran roda dua untuk petugas memiliki ukuran $35 \mathrm{~m}^{2}$. Sedangkan menurut Direktorat Jenderal Perhubungan Darat Tahun 1996, Pedoman Teknis Penyelenggaraan Fasilitas Parkir, untuk ukuran satu kendaraan roda bermotor memiliki ukuran $0.7 \times 2 \mathrm{~m}$ yaitu $1.4 \mathrm{~m}^{2}$. Untuk kendaraan roda dua pengunjung sebanyak 70 motor adalah $1.4 \mathrm{~m}^{2}$ x 70 motor adalah $98 \mathrm{~m}^{2}$, luas total $70 \mathrm{~m}^{2}+50 \%$ adalah $98+49$ adalah $147 \mathrm{~m}^{2}$. sedangkan asumsi untuk parkir kendaraan bermotor untuk petugas puskesmas adalah 17 motor adalah $1.4 \times 17$ motor adalah $23.8 \mathrm{~m}^{2}$, luas total adalah $70 \mathrm{~m}^{2}+50 \%$ adalah $23.8 \mathrm{~m}^{2}+11.9 \mathrm{~m}^{2}$ adalah 35.7 $\mathrm{m}^{2}$. Jadi kesimpulannya, area parkir kendaraan roda dua di Puskesmas Pal III tidak luas. Karena fakta dilapangan juga menunjukkan motor pengunjung dan motor petugas parkirnya melebihi kapasitas yang disediakan.

\section{Kesimpulan}

Berdasarkan evaluasi pasca huni terhadap aspek fungsional pada Puskesmas Pal III telah didapat beberapa kesimpulan sesuai dengan variabel unit amatan. Dari hasil pengamatan kondisi eksisting dan hasil kuesioner terhadap pengguna dapat disimpulkan bahwa ruang-ruang yang ada pada bangunan Puskesmas Pal III telah difungsikan sesuai dengan fungsinya dan suasana ruang terkait kualitas ruang (pencahayaan, suhu, akustik) dinilai cukup nyaman. Berdasarkan Permenkes RI Nomor 75 Tahun 2014, tata letak ruang sudah memenuhi standar hubungan ruang dan zonasinya juga telah dikelompokkan berdasarkan fungsi pelayanan. Kesimpulan terkait sirkulasi (alur/akses) dilihat dari Permenkes RI Nomor 75 tahun 2014 serta hasil kuesioner pengunjung dan petugas puskesmas cukup mudah dijangkau meskipun ruang tunggu umum pada puskesmas tersebut tidak luas untuk alur sirkulasi. Dari beberapa sampel ruang yang diteliti mengenai dimensi ruang, ukuran ruang sudah cukup luas bangi pengguna, meskipun terdapat ruang yang tidak memenuhi standar ukuran ruang seperti area parkir motor pengunjung yang melebihi kapasitas. 


\section{Ucapan Terima Kasih}

Ucapan terima kasih disampaikan kepada Bapak Muhammad Nurhamsyah, ST, M.Sc selaku Ketua Prodi Arsitektur sekaligus dosen pembimbing utama, Ibu Lestari, ST, MT selaku dosen pembimbing pendamping, serta kepada seluruh dosen dan staf Program Studi Arsitektur Universitas Tanjungpura.

\section{Daftar Acuan}

Kementerian Kesehatan Republik Indonesia. (2004). Keputusan Menteri Kesehatan Republik Indonesia Nomor 128/MENKES/SK/II/2014 tentang Kebijakan Dasar Pusat Kesehatan Masyarakat. Jakarta, Indonesia: Kementerian Kesehatan Republik Indonesia

Kementerian Kesehatan Republik Indonesia. (2014). Peraturan Menteri Kesehatan Republik Indonesia Nomor 75 Tahun 2014 tentang Pusat Kesehatan Masyarakat. Jakarta, Indonesia: Kementerian Kesehatan Republik Indonesia

Hatmoko, A.U. (2010). Arsitektur Rumah Sakit. Yogyakarta, Indonesia: Global Rancang Selaras

Sudibyo, S. (1989). Aspek Fungsi dan Teknis Post Occupancy Evaluation dan Beberapa Metodologi Penelitian. Jakarta, Indonesia: Universitas Trisakti

Suryadhi. (2005). Evaluasi Pasca Huni Instalasi Rawat Darurat di Badan Rumah Sakit Umum Tabanan. Yogyakarta, Indonesia: Universitas Gadjah Mada 